\title{
A study on the air permeability as affected by compression of three French soils
}

\author{
Anh Minh Tang ${ }^{1}$, Yu-Jun Cui ${ }^{1,2}$, Guy Richard $^{3}$, Pauline Défossez ${ }^{4}$
}

${ }^{1}$ Ecole des Ponts ParisTech, U.M.R. Navier/CERMES, 6 et 8, avenue Blaise Pascal, Cité Descartes, Champs-sur-Marne, 77455 Marne La Vallée cedex 2, France.

2 The China Three Gorges University, Yichang 443002, China

${ }^{3}$ INRA, 2163 avenue de la Pomme de Pin - CS 40001 - Ardon, 45075 Orléans Cedex 2, France.

${ }^{4}$ INRA, UMR614 FARE, 2 Esplanade Roland Garros, BP 224, 51686 Reims cedex 2, France.

\section{Corresponding author}

Prof. Yu-Jun Cui

\section{ENPC/CERMES}

6 et 8 , av. Blaise Pascal

Cité Descartes, Champs-sur-Marne

77455 Marne La Vallée cedex 2

France

Tel: 33164153550

Fax : 33164153562

E-mail : cui@cermes.enpc.fr 


\begin{abstract}
Soil air permeability is one of the most important parameters which govern the aeration in agricultural soils and thus has a significant effect on the plant growth and crop production. Therefore, it appears important, when analysing the effect of soil compaction due to agricultural machinery, to correlate air permeability with soil capacity parameters such as air-filled porosity, degree of saturation, water content, etc. In the present work, the relationship between air permeability, soil capacity parameters and vertical stress was analysed by performing confined uniaxial compression tests accompanied by air permeability measurements. Three French soils having different textures were studied. Tests were performed on remoulded and undisturbed soils, at various initial dry bulk densities and water contents. For the remoulded soils, the air permeability has been found strongly correlated with the applied vertical stress for sandy loam; by contrast, no obvious correlation could be established for clay. As far as the undisturbed soils are concerned, the air permeability could be correlated with the air-filled porosity for sandy loam and siltyclayey loam but also no evident correlation could be established for clay. Examination of an existing model predicting the air permeability from the air-filled porosity using one tortuosity/connectivity parameter showed that this parameter varies in a small range for sandy soils and in a larger range for clayey soils.
\end{abstract}

Keywords: air permeability, confined uniaxial compression test, air-filled porosity, degree of saturation, vertical stress, void ratio. 


\section{Introduction}

Prevention of soil degradation is an important issue in the context of intensive agriculture and forest exploitation. Compaction by traffic has been identified as a major process that affects the production and the environment by changing the soil structure and the physical properties of soils. It changes the mechanical strength, water and gas transports and thus affects the root and shoot growth. It changes also soil nitrogen and carbon cycles and increases soil erosion due to water flow (Soane and van Ouwerkerk, 1994). Quantifying the soil damage by compaction is therefore of importance when establishing strategies for farming and forest management on a local scale and for environmental protection measures on a larger scale. The evaluation of the soil compaction effects on soil physical properties is generally based on the consideration of the changes in soil mechanical strength, aeration and hydraulic properties (Horn et al., 1995; Kozlowski, 1999; Lipiec and Hatano, 2003; SchäferLandefeld et al., 2004; Hemmat and Adamchuk, 2008). Different approaches have been proposed to assess soil degradation due to compaction using relations between soil compaction parameters and soil capacity parameters such as air-filled porosity, degree of saturation, water content, etc: (i) Håkansson (1990) described the soil compactness in terms of relative soil porosity variations; (ii) Koolen and Kuipers (1989) examined the soil sensitivity to compaction and proposed various compaction criteria in terms of variations of soil strength parameters such as the pre-compression pressure; (iii) Horn et al. (2007) and Mosaddeghi et al. (2007) investigated the relationships between applied stress and soil air permeability; (iv) Håkansson and Lipiec (2000) analysed soil compaction using relations between soil capacity parameters and air permeability. Note that after Horn and Kutilek (2009), a capacity parameter defines a general status, while an intensity parameter includes dynamic aspects over time and space. Goss and Ehlers (2010) presented their disagreement about these definitions, arguing that both intensity and capacity properties can vary in both space and time. In the present work, the term "capacity parameter" is adopted and it defines a general status, i.e., the composition of a given volume but not the internal structure and function (as proposed by Horn and Kutilek, 2009); at the same time, it is admitted that the capacity parameters can vary with time (following Goss and Ehlers, 2010).

Laboratory studies on air permeability have shown its dependency on various soil parameters related to the capacity parameters, such as the degree of saturation (Seyfried and Murdock, 1997; Juca and Maciel, 2006), the water content (Sanchez-Giron et al., 1998) and the air-filled porosity (Olson et al., 2001; Moldrup et al., 2003). In general, the air permeability is lower at a higher degree of saturation with a lower air-filled porosity. Based on the experimental data of compacted silty soil, Delage et al. (1998) concluded that airfilled porosity is the unique parameter affecting the air permeability. Moon et al. (2008) found that the air permeability of compacted soils depends on the compaction energy as well as the moisture content at moulding; the lowest value of air permeability being at the optimum moisture content (maximum dry unit weight). Studies on undisturbed and repacked soils have shown significant effects of the soil structure and pore-space characteristics on the air permeability (O'Sullivan et al., 1999; Moldrup et al., 2001; Tuli et al. 2005; Dörner and Horn, 2006). It has been found that the air permeability was greatly reduced for repacked soils. As far as the anisotropy is concerned, the air permeability measured in the vertical direction has been found higher than in the horizontal direction due to the presence of biopores and vertical cracks. For further analysis about the air permeability dependency on the water and air contents, Tuli et al. (2005) fitted the experimental data to the model proposed by Mualem (1976) and analyzed the fitting parameters. Similar studies were 
performed by Seyfried and Murdock (1997), Moldrup et al. (2001), Moldrup et al. (2003), Kamiya et al. (2006), and Dörner and Horn (2006), showing that it is appropriate to evaluate the changes in soil pores structure based on the measurement of air permeability.

In addition to the soil capacity parameters, the effect of applied stress has been also reported by various authors. Mosaddeghi et al. (2007) noted that cyclic loading is not always accompanied by significant irreversible strain but it could decrease the air permeability by one order of magnitude. The effects of stress state on air permeability were also reported by Horn et al. (1995) and Sanchez-Giron et al. (1998). Other factors affecting air permeability have been also observed: the matric suction (Samingan et al., 2003) and the wetting/drying process (Kamiya et al., 2006). Even if the matric suction can be related to the capacity parameters (i.e. degree of saturation), it is usually considered as a stress parameter (see Gens and Alonso 1992). On the whole, it has been observed that the air permeability coefficient decreases when the stress increases or when the matric suction decreases; the relationships between air permeability coefficient and suction showed hysteresis in drying and wetting processes.

It can be concluded that air permeability has been recognised as one of the most appropriate parameters for soil compaction assessment. Nevertheless, examination of the studies mentioned above shows that the conclusions made by the authors were based on the results obtained on either one soil or a limited range of water content and porosity. The present work aims at analysing the effects of soil capacity parameters on air permeability for three French soils of various textures, with a large range of water content and porosity. Air permeability was measured in oedometer cell using the technique developed by Yoshimi and Osterberg (1963) and Delage et al. (1998). Emphasis was put on the effects of various parameters: soil type (sandy loam, silty clay loam and clay), vertical stress $(15-800 \mathrm{kPa})$, initial dry bulk density $\left(0.98-1.66 \mathrm{Mg} \mathrm{m}^{-3}\right)$ and initial water content $(14.0-40.5 \%)$. A comprehensive analysis of the obtained data was made and allowed identifying the most relevant parameters which affect the soil air permeability.

\section{Materials and method}

The studied soils were taken from three sites in France: (i) Le Breuil; (ii) Avignon; (iii) Epernay. Le Breuil is an experimental forest site located in the Morvan $\left(47^{\circ} 18^{\prime} \mathrm{N}, 4^{\circ} 4^{\prime} \mathrm{E}\right.$, centre of France) where monospecific plantation have been conducted since thirty years (oaks, beech, spruce and Douglas fir); it involves a sandy loam (Dystric Cambisol). The Avignon site is a sugar beet field $\left(43^{\circ} 55^{\prime} \mathrm{N}, 4^{\circ} 53^{\prime} \mathrm{E}\right.$, south of France). The soil is calcareous with a silty clay loam texture (Calcaric Cambisol). The Epernay site is an experimental site managed by the CIVC - Technical Institute for Champagne Wine $\left(49^{\circ} \mathrm{N}, 3^{\circ} 56^{\prime} \mathrm{E}\right.$, east of France) and the soil involved is calcareous with a clay texture (Calcaric Cambisol). Some physical and chemical properties of the studied soils are presented in Table 1. The soil properties were determined following the French Standard for Geotechnical Engineering: the particle density was determined using water pycnometer on soil sieved at $2 \mathrm{~mm}$; the Atterberg limits were determined on soil sieved at $0.4 \mathrm{~mm}$; and the blue value was determined using the Methylene blue absorption method on soil sieved at $0.5 \mathrm{~mm}$. The organic carbon content is 82.8 g. kg ${ }^{-1}$ for Le Breuil soil, 10.2 g. $\mathrm{kg}^{-1}$ for Avignon soil and $16.8 \mathrm{~g} . \mathrm{kg}^{-1}$ for Epernay soil. Soil texture was classified following FAO-UNESCO (1974) system (after Jones et al., 2003) and USDA classification that are based on the particle size distribution. According to FAO classification, the texture of the tested soils varies from 
medium to fine. This classification was in good agreement with the plasticity indexes and the blue values, i.e., the finer the soil texture the higher the plasticity index and the larger the blue value. Note that the physical and chemical properties of the soils presented in Table 1 were determined from a mixture of soil taken from a layer of $60 \mathrm{~cm}$ in thickness. The variability of these properties within the depth (in the range of $0-60 \mathrm{~cm}$ ) was therefore not considered in this study.

Remoulded samples were tested for the topsoil layer $(0-30 \mathrm{~cm})$ depth which is frequently tilled whereas undisturbed samples were tested for the subsoil layer $(30-60 \mathrm{~cm}$ depth) where compaction is persistent. For the preparation of remoulded samples, the topsoil was airdried, crushed and passed through a 2-mm sieve. It was then wetted by spraying distilled water to achieve the desired water content and then stocked in a hermetic box for 24 hours for water homogenization. Finally, the soil was poured directly into the oedometer cell and manually compacted.

For the preparation of undisturbed samples, a core sampler of $70-\mathrm{mm}$ high, $150 \mathrm{~mm}$ in inner diameter and $1 \mathrm{~mm}$ in thickness, was pushed vertically into the subsoil layer $(30-60 \mathrm{~cm}$ depth) in the field. The soil cylinders were then wetted by spraying distilled water to achieve the desired water content and then covered by a plastic film for 24 hours for water homogenization. Finally, the soil specimen $(70 \mathrm{~mm}$ in diameter and $20 \mathrm{~mm}$ in height) was trimmed directly from the cylinder and inserted into the oedometer cell. When a drying process was involved, the soil cylinder was air-dried for 2 hours, and then covered by plastic film for 6 hours. The procedure was repeated until the desired water content was achieved. This drying process allowed the soil to be prevented from any dry-cracking during the preparation. Finally, as for the wet samples, the soil specimen was prepared by trimming and inserted into the oedometer cell.

The experimental setup developed by Delage et al. (1998) was used for the measurement of soil air permeability. The soil sample was installed in an oedometer cell. The basis of the cell was connected to a tank of large volume $\left(V=3120 \mathrm{~cm}^{3}\right)$ and a U-shaped manometer. When measuring the air permeability, an initial low value of air pressure was applied in the tank ( $p=6 \mathrm{kPa}$, that corresponds to a water column of $0.60 \mathrm{~m}$ high); that induces an air flow through the soil specimen from the basis of the cell toward the upper surface. Delage et al. (1998) recommended an air pressure lower than $8 \mathrm{kPa}$ for this method in order to ensure the validity of Darcy's law. The reduction of the air pressure in the tank was recorded as a function of the elapsed time, enabling the calculation of air permeability (see Delage et al. 1998 for more details).

After the installation of the soil specimen, a low vertical stress $(15 \mathrm{kPa})$ was applied to ensure a good contact between the piston and the soil surface. The vertical stress was incrementally applied to 30, 50, 100, 200, 300, 600, $800 \mathrm{kPa}$. Each stress level was maintained for $5 \mathrm{~min}$ and the vertical displacements were recorded at the end of each step using a LVDT (linear variable differential transformer) to an accuracy of $\pm 0.001 \mathrm{~mm}$. Note that the short loading duration of 5 min was defined based on the values generally adopted when studying the compaction behaviour of agricultural soils under loading by a tractor vehicle (Keller et al., 2004; Saffih-Hdadi et al., 2009). After $5 \mathrm{~min}$, the piston was blocked to keep the soil volume constant and the measurement of air permeability was performed. Note that the piston blockage did not cancel the applied stress. After the air permeability measurement, the piston was un-blocked and the soil was further loaded. The test was stopped when no air flow was observed during the air permeability measurement or when 
the maximum load $(800 \mathrm{kPa})$ was applied. At the end of each test, the soil sample was taken out of the cell and its dimension was measured using a calliper to an accuracy of $\pm 0.001 \mathrm{~mm}$. Its final water content was determined by oven-drying at $105^{\circ} \mathrm{C}$ for 24 hours. The final void ratio and the degree of saturation were then determined. The initial void ratio was back-calculated using the final void ratio and the total displacement measured.

A total of 27 samples were prepared: 9 undisturbed samples of the subsoil layers and 18 remoulded samples of the topsoil layers. Their initial parameters (void ratio, $e_{i}$; water content, $w_{i}$; dry bulk density, $\rho_{i}$; degree of saturation, $S_{r i}$; air-filled porosity, $V_{a} / V$ ) are presented in Table 2. Note that the degree of saturation $S_{r}$ is defined as the ratio of the volume of pore-water to the volume of void; it can be calculated from the water content $(w)$, void ratio $(e)$, particle density $\left(\rho_{s}\right)$ and the density of water $\left(\rho_{w}\right)$ as follows:

$$
S_{r}=\frac{\rho_{s}}{\rho_{w}} \frac{w}{e}
$$

The air-filled porosity $V_{a} / V$, the degree of saturation $S_{r}$ and void ratio $e$ are related by the following equation:

$$
\frac{V_{a}}{V}=\frac{e\left(1-S_{r}\right)}{1+e}
$$

Tests on the remoulded specimens were performed on the soil from Le Breuil that has the lowest clay content and on the soil from Epernay that has the highest clay content. Nine tests were performed on each soil: three values of $w_{i}$ were considered; for each value of $w_{i}$, the soil was compacted at three dry densities ranging from 0.98 to $1.47 \mathrm{Mg} . \mathrm{m}^{-3}$. In the case of undisturbed specimens, four values of $w_{i}$ were considered for the soil from Avignon, three values of $w_{i}$ for the soil from Le Breuil, and two values of $w_{i}$ for the soil from Epernay.

\section{Results and discussion}

\subsection{Experimental results}

The results from the tests on the remoulded soil from Le Breuil are presented in Fig. 1. The air permeability $k_{a}$ is plotted versus air-filled porosity $V_{a} / V$ (Fig. $1 a$ on a linear scale and Fig. $1 c$ on a logarithmic scale), void ratio $e$ (Fig. 1b), degree of saturation $S_{r}$ (Fig. $1 d$ ), and vertical stress $\sigma_{v}$ (Fig. 1e). Note also that the air permeability coefficient is usually plotted on a logarithmic scale when it involves a wide range of values (Kamiya et al., 2006) and on a linear scale when it involves a narrow range (Seyfried and Murdock, 1997; Moldrup et al. 2001). In this work, both scales were used in order to have a complete view of the relationship between the air permeability coefficient and the air-filled porosity. The $e-\log \sigma_{v}$ plot (Fig. $1 f$ ) corresponds to the compression curve. $V_{a} / V$ and $S_{r}$ were calculated by assuming that the gravimetric water content was constant during each test. This assumption was justified by measuring the mass of soil specimen before and after each test.

For each test, it can be observed that compression by increasing $\sigma_{v}$ decreased $e, V_{a} / V$ and increased $S_{r}$. In addition, $k_{a}$ decreased when $\sigma_{v}$ was increasing (Fig. 1e). The $k_{a}-V_{a} / V$ plots of all tests (Fig. 1a) have similar shape: at the beginning of the compression with large values of $V_{a} / V$ and $k_{a}$ decreased drastically with a large slope $\mathrm{d} k_{a} / \mathrm{d}\left(V_{a} / V\right)$ while $V_{a} / V$ remained almost constant upon compression; at higher $\sigma_{v}$ (Fig. $1 f$ ), the soil volume decreased significantly (both $e$ and $V_{d} / V$ decreased) leading to a significant decrease of the slope 
$\mathrm{d} k_{a} / \mathrm{d}\left(V_{a} / V\right)$. This shape can be also observed when plotting $k_{a}$ with other capacity parameters as $e$ (Fig. 1b) and $S_{r}$ (Fig. 1d).

The compression curves shown in Fig. $1 f$ evidence the effect of density on its compressibility. Indeed, the curves show that the looser the soil (the larger the initial void ratio) the lower the pre-compression stress, which corresponds to the stress where irrecoverable plastic strain started to take place upon further loading (Défossez and Richard, 2002; Gregory et al., 2006; Pereira et al., 2007; Tang et al., 2009). Considering for example the results of test K17 (thick lines in Fig. 1): loading from the initial vertical stress to $50 \mathrm{kPa}$ (close to the pre-compression value) did not change significantly the void ratio ( $e$ decreased from 1.39 to 1.35 , Fig. $1 f$ ). Further loading significantly decreased the void ratio by following a larger slope in the $e-\log \sigma_{v}$ plot. The first part of the compression curve (where the vertical stress is lower than $50 \mathrm{kPa}$ ) corresponds to the first part of the $k_{a}-V_{a} / V$ plot (where $V_{a} / V$ remains constant, and is equal to 0.4 ). The slope of the $k_{a}-V_{a} / V$ curve changes significantly for $V_{a} / V$ lower than $0.39\left(k_{a}\right.$ lower than $\left.6.39 \times 10^{-10} \mathrm{~m}^{2}\right)$. These values of point of maximum curvature are shown in Table 3 for all the tests. It can be noted that the points of maximum curvature on the $k_{a}-V_{a} / V$ plot (Fig. 1a) corresponds to that of the $e-\log \sigma_{v}$ plot (Fig. $1 f$ ). The similarity between the two relationships, $k_{a}$ versus capacity parameters and these parameters versus $\log \sigma_{v}$, explains the quasi-linear relationship between $k_{a}$ and $\log \sigma_{v}$ observed in Fig. 1e. Application of linear regression over the whole stress range showed that the slopes $\mathrm{d} k_{a} / \mathrm{d} \log \sigma_{v}$ of all tests are similar, ranging from $-2.7 \times 10^{-10}\left(\mathrm{~m}^{2}\right)$ (test K18) to $4.3 \times 10^{-10}\left(\mathrm{~m}^{2}\right)$ (test K20), the mean value being $-3.6 \times 10^{-10}\left(\mathrm{~m}^{2}\right)$.

The results of the remoulded soil from Epernay are presented in Fig. 2. The overall trend observed previously on the remoulded soil from Le Breuil can be also observed: the compression (with increase of $\sigma_{v}$ ) decreased $e$ and $V_{a} / V$, increased $S_{r}$ and decreased $k_{a}$. Nevertheless, unlike the remoulded soil from Le Breuil, the shapes of $k_{a}-V_{a} / V$ plots of remoulded soil from Epernay are not similar (Fig. 2a). Moreover, the range of $k_{a}$ of the soil from Epernay $\left(k_{a}=5 \times 10^{-12}\right.$ to $\left.2 \times 10^{-9} \mathrm{~m}^{2}\right)$ was larger than that of the soil from Le Breuil $\left(k_{a}\right.$ $=1 \times 10^{-10}$ to $1 \times 10^{-9} \mathrm{~m}^{2}$ ). When analysing the $k_{a}-\log \sigma_{v}$ plots (Fig. $2 e$ ), the linear trend was not as clear as in the case of Le Breuil (Fig. 1e). In addition, the range of the slope $\mathrm{d} k_{a} / \mathrm{d} \log \sigma_{v}$ was larger, from $-3.1 \times 10^{-12}\left(\mathrm{~m}^{2}\right)$ (test K02) to $-3.0 \times 10^{-9}\left(\mathrm{~m}^{2}\right)$ (test K04). This difference can be attributed to the larger difference in the initial void ratio between the soil from Epernay $\left(e_{i}\right.$ ranges from 0.82 to 1.73$)$ and the soil from Le Breuil $\left(e_{i}\right.$ ranges from 0.9 to 1.39; see Fig. $2 f$ and Table 2).

Fig. 3 presents the results of the undisturbed soil from Le Breuil. Three values of water content were considered $(w=16.9 \%, 21.4 \%$, and $22.5 \%$ for tests $\mathrm{K} 15, \mathrm{~K} 11$, and $\mathrm{K} 14$ respectively, Table 2), corresponding to an initial air-filled porosity $V_{a} / V$ ranging from 0.20 to 0.35 (Fig. $3 a$ ) and an initial degree of saturation $S_{r}$ ranging from 30 to $60 \%$ (Fig. $3 d$ ). The $k_{a}-e$ plots of the three tests were almost identical (Fig. 3b); the $k_{a}-V_{a} / V$ plots (Fig. $3 a, c$ ) and the $k_{a^{-}} S_{r}$ plots (Fig. $3 d$ ) were similar. Again this similarity can be attributed to the close values of initial void ratio of the three tests $\left(e_{i}\right.$ ranges from 0.98 to 1.16 , see Table 2$)$ and to the similarity of the $e-\log \sigma_{v}$ curves (see Fig. $3 f$ ). In addition, the shape of the $k_{a}-V_{a} / V$ plots (Fig. $3 a$ ) and the $k_{a}-e$ plots (Fig. $3 b$ ) was also similar to that of remoulded soils from Le Breuil (Fig. 1a,b): at the beginning of the compression, $k_{a}$ decreased drastically while the volume change remained small; at higher stresses, all changes in $k_{a}$ and capacity parameters $\left(V_{a} / V\right.$ and $e$ ) upon compression were significant. Furthermore, the relationship between $k_{a}$ 
and $\log \sigma_{v}$ of the undisturbed soil from Le Breuil was no longer linear (Fig. 3e). Compared to the remoulded soil, the undisturbed soil presents a larger range of $k_{a}\left(k_{a}=5 \times 10^{-12}\right.$ to $2.5 \times 10^{-}$ $\left.{ }^{9} \mathrm{~m}^{2}\right)$.

In Fig. 4, the results of the undisturbed soil from Avignon are presented. Four values of water content in the range of $17.7-22.9 \%$ were considered (Table 2). The $e$ - $\log \sigma_{v}$ plots show two distinct families (Fig. $4 f$ ). However, the $k_{a}-V_{a} / V$ plots of all tests (Fig. $4 a$ ) are almost identical. This is because the difference in initial void ratio between the four tests is quite limited ( $e_{i}$ ranges from 0.63 to 0.76 , see Table 2 ) and moreover the shape of the four $e$ $\log \sigma_{v}$ curves are quite similar. The effect of initial void ratio can be clearly identified in other plots as the $k_{a}-e$ plots (Fig. $4 b$ ), $\log k_{a}-V_{a} / V$ plots (Fig. $4 c$ ) and $\log k_{a}-S_{r}$ plots (Fig. $4 d$ ). For instance, in Fig. $4 b$, the tests K13 and K27 show that $k_{a}$ varied from 0 to $5 \times 10^{-10}\left(\mathrm{~m}^{2}\right)$ while $e$ varied in the range from 0.52 to 0.62 for K13 and from 0.63 to 0.75 for K27. Similar observations can be made when comparing K16 and K26 in Fig. 4b. In Fig. $4 c$ and Fig. $4 d$, $k_{a}$ is plotted on a logarithmic scale, that makes the difference between the data clearer in the range of low $k_{a}$ values $\left(k_{a}<10^{-11} \mathrm{~m}^{2}\right)$. When applying linear regression over the whole stress range to the $k_{a}-\log \sigma_{v}$ plots (Fig. $4 e$ ), the slope $\mathrm{d} k_{a} / \mathrm{d} \log \sigma_{v}$ obtained showed variations ranging from $-1.5 \times 10^{-10}\left(\mathrm{~m}^{2}\right)$ (test $\left.\mathrm{K} 16\right)$ to $-4.6 \times 10^{-10}\left(\mathrm{~m}^{2}\right)$ (test K27).

The results of the two tests of the undisturbed soil from Epernay are presented in Fig. 5. Except the similar linear relationship observed on the $k_{a}-\log \sigma_{v}$ plot with a slope $\mathrm{d} k_{a} / \mathrm{d} \log \sigma_{v}$ of about $-1.9 \times 10^{-10} \mathrm{~m}^{2}$ (Fig. $5 e$ ), other curves show significant difference between the two tests. The large difference between the initial void ratio of the two tests $\left(e_{i}\right.$ ranges from 1.05 to 1.22 , see Fig. $5 f$ and Table 2) can also explain this difference. When comparing the results of remoulded and undisturbed soil from Epernay, it was observed that the orders of magnitude of $k_{a}$ are similar: $k_{a}=5 \times 10^{-12}-1 \times 10^{-9} \mathrm{~m}^{2}$ for $V_{a} / V=0-0.2, e=0.8-1.2, S_{r}=65$ $-100 \%$.

The effect of $\sigma_{v}$ on $k_{a}$ has been observed in several studies. Horn et al. (1995) reported the study of Semmel (1993) on the stress-dependent changes in air permeability observed from tests on soil samples from 0.4-m depth in a Luvisol derived from loess, at a matric suction of $6 \mathrm{kPa}$. Upon additional loading, it was observed that $k_{a}$ decreased sharply as soon as the precompression stress value (100 kPa) was exceeded. In the work of Mosaddeghi et al. (2007), $k_{a}$ was measured on five remoulded soils from sandy loam to clay at four matric suctions $(10,20,50$ and $80 \mathrm{kPa})$ and three axial stresses $(200,400$, and $600 \mathrm{kPa})$. The results showed that cyclic loading was not always accompanied by significant irrecoverable strain but could result in up to 10 times decrease in air permeability at low matric suctions. Linear regression was applied to the relationship between the logarithm of $k_{a}$ and the logarithm of vertical stress. In the present work, it was observed that the shape of $k_{a}-\sigma_{v}$ relationship is different from that described by Semmel (1993) and Mossaddeghi et al. (2007) and a satisfactory linear relationship can be obtained on a semi-logarithmic scale. This difference may be explained by the test conditions: in the study of Semmel (1993) and Mossaddeghi et al. (2007), the soil was compressed under constant suction condition while in the present work the tests were carried out at constant water contents thus decreasing suctions. SanchezGiron et al. (1998) also measured $k_{a}$ in confined uniaxial compression conditions. The measurements were performed on five remoulded soils having various textures at four vertical stresses $(50,100,200$, and $400 \mathrm{kPa})$ and five water contents $(5,10,15,20$, and $25 \%$ ). The results showed that the effects of water content and applied stress on the 
compaction process (thus, on the air permeability changes) depend on soil texture. This is in agreement with the results obtained in the present work where the behaviour of remoulded soil from Epernay (Fig. 2) was found to be significantly different from that of Le Breuil (Fig. 1).

\subsection{Evaluation of the Moldrup et al. (2003) model}

To further analyse the experimental data, the model proposed by Moldrup et al. (2003) was evaluated by determining the single tortuosity/connectivity parameter involved in the model, $\eta$. This model is expressed by the following equation:

$$
k_{a} / k_{a}^{*}=\left(\varepsilon / \varepsilon^{*}\right)^{\eta}
$$

where $\varepsilon=V_{a} / V, k_{a}^{*}$ and $\varepsilon^{*}$ are reference point values of air permeability and air-filled porosity at a given soil matric potential.

Eq. (3) can be re-written as follows:

$k_{a}=(\varepsilon)^{\eta}\left(k_{a}^{*} / \varepsilon^{* \eta}\right)$

In the work of Moldrup et al. (2003), the parameter $\varepsilon^{*}$ was determined from the point corresponding to a suction of $100 \mathrm{~cm}$ of water $(10 \mathrm{kPa})$ on the water retention curve. The parameter $k_{a}^{*}$ was the measured value of $k_{a}$ corresponding to this value of $\varepsilon^{*}$. The tortuosity/connectivity parameter, $\eta$, was fitted from the slope of the soil-water retention curve plotted in a $\log (\theta)-\log (s)$ coordinate system $(\theta$ is the volumetric water content and $s$ is the soil suction). In the present work, Eq. (4) was used to fit the experimental data in order to determine $\eta$. As an example, the results of the test K01 are shown in Fig. 6. The experimental results were best fitted with a power function $\left(k_{a}=a \varepsilon^{b}\right.$; where $a$ and $b$ are the two fitting parameters; $a=k_{a}^{*} / \varepsilon^{* \eta}$ and $\eta=b$ following the Eq. (4)). The results of test K01 gave a value of $\eta$ equal to 15.6 with a coefficient of determination $\left(R^{2}\right)$ of 0.985 . The values of these two parameters, $\eta$ and $R^{2}$, were determined for all tests and are summarised in Table 4.

Examination of Table 4 shows that the parameter $\eta$ of remoulded soil from Le Breuil (K17 $\mathrm{K} 25$ ) varies from 1.91 to 3.69 while that of remoulded soil from Epernay (K02 - K10) varies from 0.49 to 5.09. For test K08, only one value was available, making impossible the determination of the parameter. For undisturbed soils, $\eta$ varies from 1.59 to 3.99 for the soil from Breuil, from 2.49 to 6.74 for the soil from Avignon. In the case of the soil from Epernay, a value of 1.11 was obtained from test K12 and a very high value (15.6) was obtained from test K01. Note that in the work of Moldrup et al. (2003), $\eta$ varies from 1 to 3 for various undisturbed volcanic ash soils in Japan. The larger range of variations of parameter $\eta$ for the clay from Epernay reflects its more complex mechanism for air transfer compared to the sandy soil from Le Breuil. In other words, it seems difficult to describe the air permeability variations of one soil using a unique value of $\eta$. Gens and Alonso (1992) also reported that the hydro-mechanical behaviour of high plasticity unsaturated soils (clays) is significantly different from that of low plasticity unsaturated soils (sands and silts). Clayey soils having various hydric states (water content) show different properties at the level of soil aggregates (compressibility and cohesion between aggregates). Thus the soil structure change upon mechanical loading (compression) of clayey soils strongly depends on the hydric state. On the contrary, the microstructural properties of low plasticity unsaturated 
soils (sands and silts) are significantly less sensitive to the hydric changes. That explains also why predictive models are usually applied to sandy soils only (Poulsen et al., 2007; Moldrup et al., 2001; Tuli et al., 2005; Dörner and Horn, 2006). It is worth mentioning that there are a large difference in organic carbon content between the three soils studied ( 82.8 g. $\mathrm{kg}^{-1}$ for Le Breuil, 10.2 g.kg ${ }^{-1}$ for Avignon and 16.8 g. $\mathrm{kg}^{-1}$ for Epernay). This parameter would have also an effect on soil structure and then on the air permeability. Dexter (2004a) proposed a soil physical parameter, $S$, as an index of soil physical quality. Examination of various experimental results showed that $S$ was higher when the organic carbon content was higher. In addition, Dexter (2004b) showed a higher hydraulic conductivity at higher $S$. These observations are in agreement with the present study where the soil from Le Breuil that has the highest organic carbon content showed higher air permeability.

\section{Conclusion}

In an attempt to study the relationships between soil capacity parameters and the air permeability coefficient, air permeability tests were carried out on three soils at various textures, densities, water contents and types (remoulded soils from the topsoil layer and undisturbed soils from the subsoil layer). Tests at various densities and water contents were carried out. For each test performed, the air permeability coefficient $k_{a}$ was plotted versus various parameters $\left(V_{a} / V, e, S_{r}\right.$, and $\left.\sigma_{v}\right)$ in order to examine the relationship between compaction and soil aeration. Note that relations between air permeability and the capacity parameters $\left(V_{d} / V, e, S_{r}\right)$ allow analyse of the processes involved in air transfer. The relations between $k_{a}$ and the applied stress were established in order to link the effect of applied stress with the soil physical properties.

The effects of various parameters on $k_{a}$ observed in the present work are in agreement with previous studies found in the literature: $k_{a}$ decreases when $V_{d} / V$ decreases (O'Sullivan et al., 1999; Olson et al., 2001) or $S_{r}$ increases (Delage et al., 1998; Samingan et al., 2003; Juca and Maciel, 2006).

The air permeability of the remoulded sandy loam (from Le Breuil) has a clearer correlation with the vertical stress than with other soil capacity parameters. For undisturbed soils, the air permeability of sandy loam (from Le Breuil) and silty clay loam (from Avignon) has a good correlation with soil capacity parameters. No unique correlation between the studied parameters (air permeability, void ratio, air-filled porosity, vertical stress, and degree of saturation) has been observed for both the remoulded and undisturbed clay from Epernay.

Evaluation of the model proposed by Moldrup et al. (2003) using the tests results showed that the tortuosity/connectivity parameter, $\eta$, varies in a narrow range (from 1.91 to 3.69) for the remoulded soil from Le Breuil, from 0.49 to 5.09 for the remoulded soil from Epernay, from 1.59 to 3.99 for the undisturbed soil from Le Breuil, from 2.49 to 6.74 for the undisturbed soil from Avignon, and from 1.11 to 15.6 for the undisturbed soil from Epernay. It appears then difficult to describe the air permeability variations using only one parameter for clayey soils as the soil from Epernay, especially in the undisturbed state.

It is finally worth noting that the present study was limited to three soil textures, from sandy to clayey soil. Further studies should be performed on other soils in order to refine the analysis. In addition, it would be interesting to further investigate the effects of water retention capacity, organic carbon content, and soil heterogeneity with depth, etc. 


\section{Acknowledgements}

This work was carried out under the project "Soil degradation due to compaction" with the financial support of (1) the "ANR-Agence Nationale de la Recherche - The French National Research Agency » under the "Programme Agriculture et Développement Durable», project «ANR-05-PADD-013 », (2) the Ministry in charge of Environment under the programme GESSOL2 "Impact des pratiques agricoles sur le sol et les eaux ». The authors are also grateful for the technical assistance of D. Boitez and F. Bornet.

\section{References}

Brooks, R.H., Corey, A.T., 1966. Properties of porous media affecting fluid flow. J. Irrig. Drain. Div. Proc. ASCE. 92(IR 2), 61-88.

Défossez, P., Richard, G., 2002. Models of soil compaction due to traffic and their evaluation. Soil Till. Res. 67, $41-64$.

Delage, P., Cui, Y. J., De Laure, E., 1998. Air flow through an unsaturated compacted silt. Proceedings of the $2^{\text {nd }}$ International Conference on Unsaturated Soils, Beijing, Vol. 1, pp. $563-568$.

Dexter, A. R., 2004a. Soil physical quality. Part I. Theory, effects of soil texture, density and organic matter, and effects on root growth. Geoderma 120, 210 - 214.

Dexter, A. R., 2004b. Soil physical quality. Part III. Unsaturated hydraulic conductivity and general conclusions about S-theory. Geoderma 120, 227 - 239.

Dörner, J., Horn, R., 2006. Anisotropy of pore functions in structured Stagnic Luvisols in the Weichselian moraine region in N Germany. J. Plant Nutr. Soil Sci. 169, 213 - 220.

FAO-UNESCO, 1974. FAO-UNESCO Soil Map of the World, vol. 1, Legend. UNESCO, Paris.

Gens, A., Alonso, E. E., 1992. A framework for the behaviour of unsaturated expansive clays. Can. Geotech. J. 29, 1013 - 1032.

Goss, M. J., Ehlers, W., 2010. Comment on the Editorial "The intensity-capacity concept How far is it possible to predict intersity values with capacity parameters" [R. Horn, M. Kutilek, Soil Till. Res. 103 (2009) 1 - 3]. Soil Till. Res. 106, 349 - 350.

Gregory, A.S., Whalley, W.R., Watts, C.W., Bird, N.R.A., Hallet, P.D., Whitmore, A.P., 2006. Calculation of the compression index and precompression stress from soil compression test data. Soil Till. Res. 89, 45 - 57.

Håkansson, I., 1990. A method for characterizing the state of compactness of the plough layer. Soil Till. Res. 16, 105 - 120.

Håkansson, I., Lipiec, J., 2000. A review of the usefulness of relative bulk density values in studies of soil structure and compaction. Soil Till. Res. 53, $71-85$.

Hemmat, A., Adamchuk, V.I., 2008. Sensor systems for measuring soil compaction: Review and analysis. Computers and Electronics in Agriculture 63, 89- 103.

Horn, R., Kutilek, M., 2009. The intensity-capacity concept - How far is it possible to predict intensity values with capacity parameters. Soil Till. Res. 103, $1-3$.

Horn, R., Domzal, H., Slowinska-Jurkiewicz, A., van Ouwerkerk, C., 1995. Soil compaction processes and their effects on the structure of arable soils and the environment. Soil Till. Res. 35, $23-36$. 
Horn, R., Vossbrink, J., Peth, S., Becker, S., 2007. Impact of modern forest vehicles on soil physical properties. Forest Ecology and Management 248, $56-63$.

Jones, R.J.A., Spoor, G., Thomasson, A.J., 2003. Vulnerability of subsoils in Europe to compaction: a preliminary analysis. Soil Till. Res. 73, $131-143$.

Juca, J. F. T., Maciel, F .J., 2006. Gas permeability of a compacted soil used in a landfill cover layer. Geotechnical Special Publication 147(2), 1535-1546.

Kamiya, K., Bakrie, R., Honjo, Y., 2006. A new method for the measurement of air permeability coefficient of unsaturated soil. Geotechnical Special Publication 147(2), 1741-1752.

Keller, T., Arvidsson, J., Dawidowski, J.B., Koolen, A.J., 2004. Soil precompression stress. II. A comparison of different compaction tests and stress - displacement behaviour of the soil during wheeling. Soil Till. Res. 77, $97-108$.

Koolen A.J., Kuipers H., 1989. Soil deformation under compressive forces, in Mechanics soils ed. by Larson et al. Nato ASI Series. Series E : Applied Sciences, 172.

Kozlowski, T. T., 1999. Soil compaction and growth of woody plants. Scand. J. For. Res. $14,596-619$.

Lipiec, J, Hatano, R., 2003. Quantification of compaction effects on soil physical properties and crop growth. Geoderma 2003, 107 - 136.

Moldrup, P., Olesen, T., Komatsu, T., Schjønning, P., Rolston, D. E., 2001. Tortuosity, diffusivity, and permeability in the soil liquid and gaseous phases. Soil Sci. Soc. Am. J. 65, $613-623$.

Moldrup, P., Yoshikawa, S., Olesen, T., Komatsu, Rolston, D. E., 2003. Air permeability in undisturbed volcanic ash soils: predictive model test and soil structure fingerprint. Soil Sci. Soc. Am. J. 67, 32 - 40.

Moon, S., Nam, K., Kim, J.K., Hwan, S.K., Chung, M., 2008. Effectiveness of compacted soil liner as a gas barrier layer in the landfill final cover system. Waste Management 28, 1909 - 1914.

Mosaddeghi, M. R., Koolen, A. J., Hajabbasi, M. A., Hemmat, A., Keller, T., 2007. Suitability of pre-compression stress as the real critical stress of unsaturated agricultural soils. Biosystems Engineering 98, 90 - 101.

Mualem, Y., 1976. A new model for predicting the hydraulic conductivity of unsaturated porous media. Water Resour. Res. 12, 513 - 522.

O’Sullivan, M. F., Robertson, E. A. G., Henshall, J. K., 1999. Shear effects on gas transport in soil. Soil Till. Res. 50, $73-83$.

Olson, M. S., Tillman, F. D., Choi, J .W., Smith, J. A., 2001. Comparison of three techniques to measure unsaturated-zone air permeability at Picatinny Arsenal, NJ. Journal of Contaminant Hydrology 53, 1 - 19.

Pereira, J. O., Défossez, P., Richard, G., 2007. Soil susceptibility to compaction by wheeling as a function of some properties of a silty soil as affected by the tillage system. European Journal of Soil Science 58(1), $34-44$.

Poulsen, T.G., Moldrup, P., Thorbjorn, A., Schjønning, P., 2007. Predicting Air Permeability in Undisturbed, Subsurface Sandy Soils from Air-Filled Porosity. Journal of Environmental Engineering 133(10), 995 - 1001.

Saffih-Hdada, K., Défossez, P., Richard, G., Cui, Y.J., Tang, A.M., Chaplain, V., 2009. A method for predicting soil susceptibility to the compaction of surface layers as a function of water content and bulk density. Soil Till. Res. 105, $96-103$. 
Samingan, A. S., Leong, E. C., Rahardjo, H., 2003. A flexible wall permeameter for measurements of water and air coefficients of permeability of residual soils. Can. Geotech. J. 40, 559 - 574.

Sanchez-Giron, V., Andreu, E., Hernanz, J. L., 1998. Response of five types of soil to simulated compaction in the form of confined uniaxial compression tests. Soil Till. Res. 48, $37-50$.

Schäfer-Landefeld, L., Brandhuber, R., Fenner, S., Koch, H. J., Stockfisch, N., 2004. Effects of agricultural machinery with high axle load on soil properties of normally managed fields. Soil Till. Res. 75, $75-86$.

Semmel, H., 1993. Auswirkungen kontrollierter Bodenbelastungen auf das Druckfortpflanzungsverhalten und physikalisch-mechanische Kenngrijssen von Ackerboden. Christian Albrechts University, Kiel, Germany, Schriftenreihe Inst. Pflanzenem. Bodenkd., 26,183 pp.

Seyfried, M. S., Murdock, M. D., 1997. Use of air permeability to estimate infiltrability of frozen soil. Journal of Hydrology 202, 95 - 107.

Soane, B. D. and van Ouwerkerk, C., 1994. Soil compaction problems in world agriculture. In: B.D. Soane and C. van Ouwerkerk, Editors, Soil Compaction in Crop Production, Elsevier, Amsterdam, Netherlands (1994), pp. 1-21.

Tang A.M., Cui Y.J., Eslami J., Defossez P., 2009. Analysing the form of the confined uniaxial compression curve of various soils. Geoderma 148 (3-4), 282 - 290.

Tuli, A., Hopmans, J. W., Rolston, D. E., Moldrup, P., 2005. Comparison of air and water permeability between disturbed and undisturbed soils. Soil Sci. Soc. Am. J. 69, 1361 1371.

van Genuchten, M. T., 1980. A closed-form equation for predicting the hydraulic conductivity of unsaturated soils. Soil Sci. Soc. Am. J. 44, $892-898$.

Yoshimi Y., Osterberg J.O.1963. Compression of partially saturated cohesive soils, ASCE J. of the Soil Mechanics and Foundations Div. 89(4) 1963, 1-24. 


\section{List of Tables}

Table 1. Some physical and chemical properties of studied soils (determined from a mixture of soils taken from the depth of $0-60 \mathrm{~cm}$ ).

Table 2. Initial conditions of the tests performed $\left(k_{a}\right.$ : air permeability coefficient; $V_{d} / V$ : airfilled porosity; $e_{i}$ : initial void ratio; $S_{r i}$ : initial degree of saturation; $\rho_{i}$ : initial dry density; w: water content; Ep.: Epernay; Br: Le Breuil; Av.: Avignon)

Table 3: Results of the remoulded soil from Le Breuil - values corresponding to the points of maximum curvature in the $k_{a}-V_{a} / V$ plots and $e-\log \sigma_{v}$ plots $\left(k_{a}\right.$ : air permeability coefficient; $V_{a} / V$ : air-filled porosity; $e$ : void ratio; $\sigma_{v}$ : vertical stress)

Table 4: Fitting parameters following the model of Moldrup et al. (2003)

( $\eta$ :tortuosity/connectivity parameter $; R^{2}$ : coefficient of determination; Ep.: Epernay; Br: Le

Breuil; Av.: Avignon)

\section{List of Figures}

Fig. 1. Results of the remoulded soil from Le Breuil $\left(\mathrm{k}_{a}\right.$ : air permeability coefficient; $V_{d} / V$ : air-filled porosity; $e$ : void ratio; $S_{r}$ : degree of saturation; $\sigma_{v}$ : vertical stress; $\rho_{i}$ : initial dry density; $w$ : water content)

Fig. 2. Results of the remoulded soil from Epernay ( $\mathrm{k}_{a}$ : air permeability coefficient; $V_{a} / V$ : air-filled porosity; $e$ : void ratio; $S_{r}$ : degree of saturation; $\sigma_{v}$ : vertical stress; $\rho_{i}$ : initial dry density; $w$ : water content)

Fig. 3. Results of the undisturbed soil from Le Breuil $\left(\mathrm{k}_{a}\right.$ : air permeability coefficient; $V_{a} / V$ : air-filled porosity; $e$ : void ratio; $S_{r}$ : degree of saturation; $\sigma_{v}$ : vertical stress; $w$ : water content) Fig. 4. Results of the undisturbed soil from Avignon $\left(\mathrm{k}_{a}\right.$ : air permeability coefficient; $V_{d} / V$ : air-filled porosity; $e$ : void ratio; $S_{r}$ : degree of saturation; $\sigma_{v}$ : vertical stress; $w$ : water content) Fig. 5. Results of the undisturbed soil from Epernay $\left(\mathrm{k}_{a}\right.$ : air permeability coefficient; $V_{a} / V$ : air-filled porosity; $e$ : void ratio; $S_{r}$ : degree of saturation; $\sigma_{v}$ : vertical stress; $w$ : water content) Fig. 6. Results of test K01 - Comparison between the experimental results and the best fitted curve using the model of Moldrup et al. (2003). 
Table 1. Some physical and chemical properties of studied soils (determined from a mixture of soils taken from the depth of $0-60 \mathrm{~cm}$ ).

\begin{tabular}{llll}
\hline Site & Le Breuil & Avignon & Epernay \\
Particle density $\left(\mathrm{Mg} \cdot \mathrm{m}^{-3}\right)$ & 2.56 & 2.71 & 2.68 \\
Liquid limit $(\%)$ & 58 & 31 & 49 \\
Plastic limit $(\%)$ & 51 & 20 & 29 \\
Plasticity index $(\%)$ & 7 & 11 & 20 \\
Organic carbon content $\left(\mathrm{g} \cdot \mathrm{kg}^{-1}\right)$ & 82.8 & 10.2 & 16.8 \\
Methylene blue absorption $\left(\mathrm{g}^{-1} \mathrm{logg}^{-1}\right)$ & 0.4 & 2.3 & 7.4 \\
Particle size distribution $\left(\mathrm{g} \cdot \mathrm{g}^{-1}\right):$ & & & \\
$\quad$ Clay $(<2 \mu \mathrm{m})$ & 0.19 & 0.34 & 0.47 \\
$\quad$ Silt $(2-50 \mu \mathrm{m})$ & 0.23 & 0.51 & 0.33 \\
$\quad$ Sand $(50-2000 \mu \mathrm{m})$ & 0.58 & 0.15 & 0.20 \\
USDA Classification & Sandy loam & Silty clay loam & Clay \\
FAO Classification & Medium & Medium fine & Fine \\
FAO Taxonomy & Dystric cambisol & Calcaric cambisol & Calcaric \\
& & \multicolumn{2}{c}{ cambisol } \\
\hline
\end{tabular}


Table 2. Initial conditions of the tests performed ( $k_{a}$ : air permeability coefficient; $V_{a} / V$ : air-filled porosity; $e_{i}$ : initial void ratio; $S_{r i}$ : initial degree of saturation; $\rho_{i}:$ initial dry density; w: water content; Ep.: Epernay; Br: Le Breuil; Av.: Avignon)

\begin{tabular}{|c|c|c|c|c|c|c|c|c|}
\hline Test No. & Soil & Description & $e_{i}$ & $\begin{array}{l}w \\
(\%)\end{array}$ & $\begin{array}{l}\rho_{i} \\
\left(\mathrm{Mg} \cdot \mathrm{m}^{-3}\right)\end{array}$ & $\begin{array}{l}S_{r i} \\
(\%)\end{array}$ & $V_{a} / V$ & $\begin{array}{l}k_{a} \\
\left(10^{-10} \mathrm{~m}^{2}\right)\end{array}$ \\
\hline K01 & Ep. & Undisturbed & 1.05 & 26.2 & 1.31 & 67 & 0.17 & 2.28 \\
\hline K02 & Ep. & Remoulded & 0.94 & 32.5 & 1.38 & 92 & 0.04 & 0.09 \\
\hline K03 & Ep. & Remoulded & 1.73 & 25.8 & 0.98 & 40 & 0.37 & 12.46 \\
\hline K04 & Ep. & Remoulded & 1.43 & 37.8 & 1.10 & 70 & 0.18 & 16.30 \\
\hline K05 & Ep. & Remoulded & 1.59 & 32.5 & 1.03 & 55 & 0.28 & 17.07 \\
\hline K06 & Ep. & Remoulded & 1.25 & 32.5 & 1.19 & 70 & 0.17 & 8.85 \\
\hline K07 & Ep. & Remoulded & 1.14 & 37.8 & 1.25 & 88 & 0.06 & 0.33 \\
\hline K08 & Ep. & Remoulded & 0.90 & 32.5 & 1.41 & 97 & 0.02 & 0.04 \\
\hline K09 & Ep. & Remoulded & 0.82 & 25.6 & 1.47 & 82 & 0.07 & 6.85 \\
\hline K10 & Ep. & Remoulded & 0.92 & 25.6 & 1.39 & 74 & 0.12 & 5.72 \\
\hline K11 & $\mathrm{Br}$ & Undisturbed & 1.13 & 21.4 & 1.20 & 49 & 0.27 & 24.65 \\
\hline K12 & Ep. & Undisturbed & 1.22 & 40.5 & 1.21 & 89 & 0.08 & 3.13 \\
\hline K13 & Av. & Undisturbed & 0.63 & 17.7 & 1.66 & 89 & 0.10 & 5.23 \\
\hline K14 & $\mathrm{Br}$ & Undisturbed & 0.98 & 22.5 & 1.20 & 58 & 0.21 & 8.59 \\
\hline K15 & $\mathrm{Br}$ & Undisturbed & 1.16 & 16.9 & 1.18 & 36 & 0.34 & 19.81 \\
\hline K16 & Av. & Undisturbed & 0.65 & 19.8 & 1.64 & 80 & 0.08 & 2.12 \\
\hline K17 & $\mathrm{Br}$. & Remoulded & 1.39 & 17.3 & 1.07 & 31 & 0.40 & 10.08 \\
\hline K18 & $\mathrm{Br}$ & Remoulded & 1.09 & 17.3 & 1.22 & 40 & 0.31 & 6.60 \\
\hline K19 & $\mathrm{Br}$ & Remoulded & 0.97 & 17.3 & 1.30 & 45 & 0.27 & 8.43 \\
\hline $\mathrm{K} 20$ & $\mathrm{Br}$ & Remoulded & 1.39 & 14.0 & 1.07 & 25 & 0.44 & 10.29 \\
\hline $\mathrm{K} 21$ & $\mathrm{Br}$ & Remoulded & 1.05 & 14.0 & 1.25 & 32 & 0.35 & 8.09 \\
\hline $\mathrm{K} 22$ & $\mathrm{Br}$ & Remoulded & 0.93 & 14.0 & 1.32 & 36 & 0.31 & 7.65 \\
\hline $\mathrm{K} 23$ & $\mathrm{Br}$ & Remoulded & 1.33 & 21.0 & 1.10 & 40 & 0.34 & 8.78 \\
\hline K24 & $\mathrm{Br}$ & Remoulded & 1.03 & 21.0 & 1.26 & 50 & 0.25 & 7.92 \\
\hline $\mathrm{K} 25$ & $\mathrm{Br}$ & Remoulded & 0.90 & 21.0 & 1.34 & 61 & 0.19 & 6.68 \\
\hline $\mathrm{K} 26$ & Av. & Undisturbed & 0.75 & 22.9 & 1.55 & 80 & 0.09 & 2.17 \\
\hline $\mathrm{K} 27$ & Av. & Undisturbed & 0.76 & 21.1 & 1.54 & 74 & 0.11 & 4.94 \\
\hline
\end{tabular}


Table 3: Results of the remoulded soil from Le Breuil - values corresponding to the points of maximum curvature in the $k_{a}-V_{a} / V$ plots and $e-\log \sigma_{v}$ plots $\left(k_{a}\right.$ : air permeability coefficient; $V_{a} / V$ : air-filled porosity; $e$ : void ratio; $\sigma_{v}$ : vertical stress)

\begin{tabular}{|l|l|l|l|l|}
\hline Test No. & $\begin{array}{l}k_{a} \\
\left(10^{-10} \mathrm{~m}^{2}\right)\end{array}$ & $V_{a} / V$ & $e$ & $\begin{array}{l}\sigma_{v} \\
(\mathrm{kPa})\end{array}$ \\
\hline $\mathrm{K} 17$ & 6.39 & 0.39 & 1.35 & 50 \\
\hline $\mathrm{K} 18$ & 4.06 & 0.29 & 1.02 & 200 \\
\hline $\mathrm{K} 19$ & 5.04 & 0.25 & 0.90 & 200 \\
\hline $\mathrm{K} 20$ & 7.25 & 0.43 & 1.34 & 50 \\
\hline $\mathrm{K} 21$ & 4.58 & 0.32 & 0.97 & 200 \\
\hline $\mathrm{K} 22$ & 4.77 & 0.29 & 0.88 & 200 \\
\hline $\mathrm{K} 23$ & 5.40 & 0.32 & 1.24 & 100 \\
\hline $\mathrm{K} 24$ & 4.21 & 0.21 & 0.93 & 200 \\
\hline $\mathrm{K} 25$ & 3.71 & 0.18 & 0.85 & 200 \\
\hline
\end{tabular}


Table 4: Fitting parameters following the model of Moldrup et al. (2003)

( $\eta$ :tortuosity/connectivity parameter ; $R^{2}$ : coefficient of determination; Ep.: Epernay; Br: Le Breuil; Av.: Avignon)

\begin{tabular}{lllll}
\hline Test No. & Soil & Description & $\eta$ & $R^{2}$ \\
\hline K01 & Ep. & Undisturbed & 15.6 & 0.985 \\
K02 & Ep. & Remoulded & 0.8 & 0.872 \\
K03 & Ep. & Remoulded & 2.25 & 0.867 \\
K04 & Ep. & Remoulded & 2.67 & 0.985 \\
K05 & Ep. & Remoulded & 4.33 & 0.981 \\
K06 & Ep. & Remoulded & 5.09 & 0.999 \\
K07 & Ep. & Remoulded & 2.41 & 1.000 \\
K08 & Ep. & Remoulded & - & - \\
K09 & Ep. & Remoulded & 0.49 & 0.850 \\
K10 & Ep. & Remoulded & 1.07 & 0.994 \\
K11 & Br. & Undisturbed & 1.96 & 0.926 \\
K12 & Ep. & Undisturbed & 1.11 & 0.983 \\
K13 & Av. & Undisturbed & 3.64 & 0.988 \\
K14 & Br. & Undisturbed & 1.59 & 0.926 \\
K15 & Br. & Undisturbed & 3.99 & 0.896 \\
K16 & Av. & Undisturbed & 2.49 & 0.943 \\
K17 & Br. & Remoulded & 1.91 & 0.825 \\
K18 & Br. & Remoulded & 3.53 & 0.847 \\
K19 & Br. & Remoulded & 3.13 & 0.809 \\
K20 & Br. & Remoulded & 2.72 & 0.902 \\
K21 & Br. & Remoulded & 3.67 & 0.776 \\
K22 & Br. & Remoulded & 3.04 & 0.759 \\
K23 & Br. & Remoulded & 2.32 & 0.917 \\
K24 & Br. & Remoulded & 2.20 & 0.838 \\
K25 & Br. & Remoulded & 3.69 & 0.913 \\
K26 & Av. & Undisturbed & 5.48 & 0.973 \\
K27 & Av. & Undisturbed & 6.74 & 0.910 \\
\hline & & & &
\end{tabular}



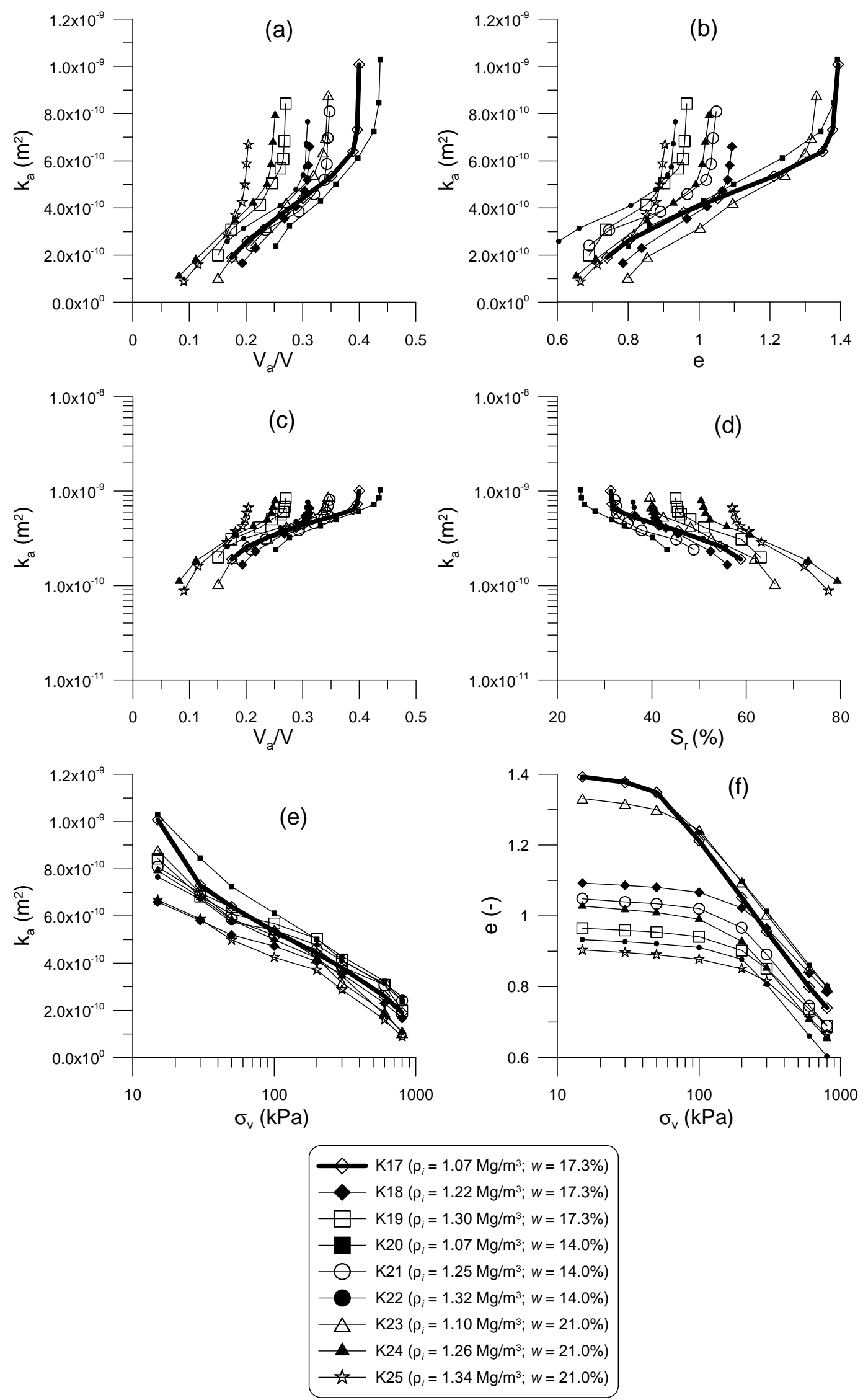

Fig. 1. Results of the remoulded soil from Le Breuil ( $k_{a}$ : air permeability coefficient; $V_{a} / V$ : air-filled porosity; $e$ : void ratio; $S_{r}:$ degree of saturation; $\sigma_{v}:$ vertical stress; $\rho_{i}$ : initial dry density; $w$ : water content) 

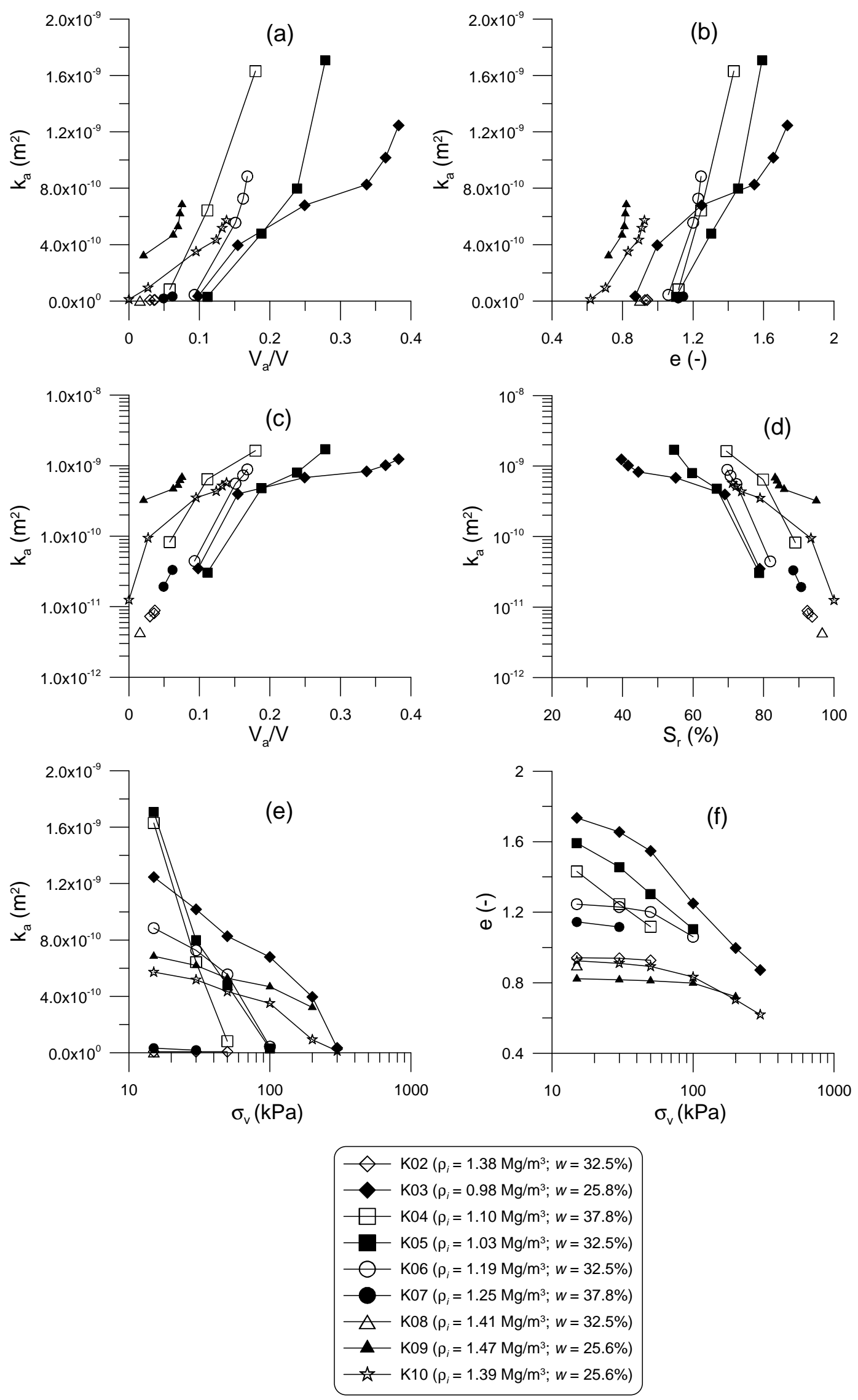

Fig. 2. Results of the remoulded soil from Epernay $\left(k_{a}\right.$ : air permeability coefficient; $V_{a} / V$ : air-filled porosity; $e$ : void ratio; $S_{r}$ : degree of saturation; $\sigma_{v}:$ vertical stress; $\rho_{i}$ : initial dry density; $w$ : water content) 

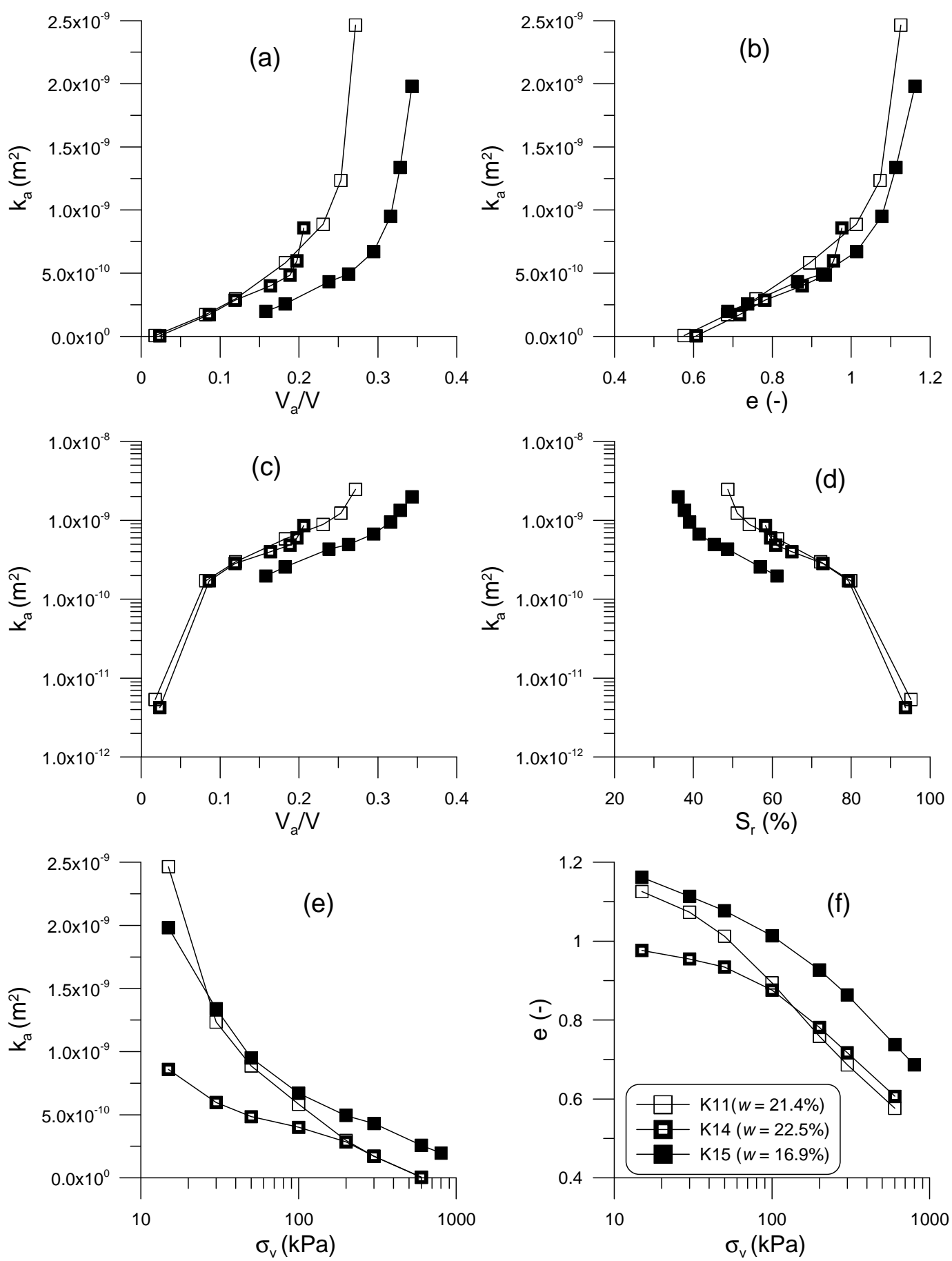

Fig. 3. Results of the undisturbed soil from Le Breuil $\left(\mathrm{k}_{a}\right.$ : air permeability coefficient; $V_{a} / V$ : air-filled porosity; $e$ : void ratio; $S_{r}$ : degree of saturation; $\sigma_{v}$ : vertical stress; $w$ : water content) 

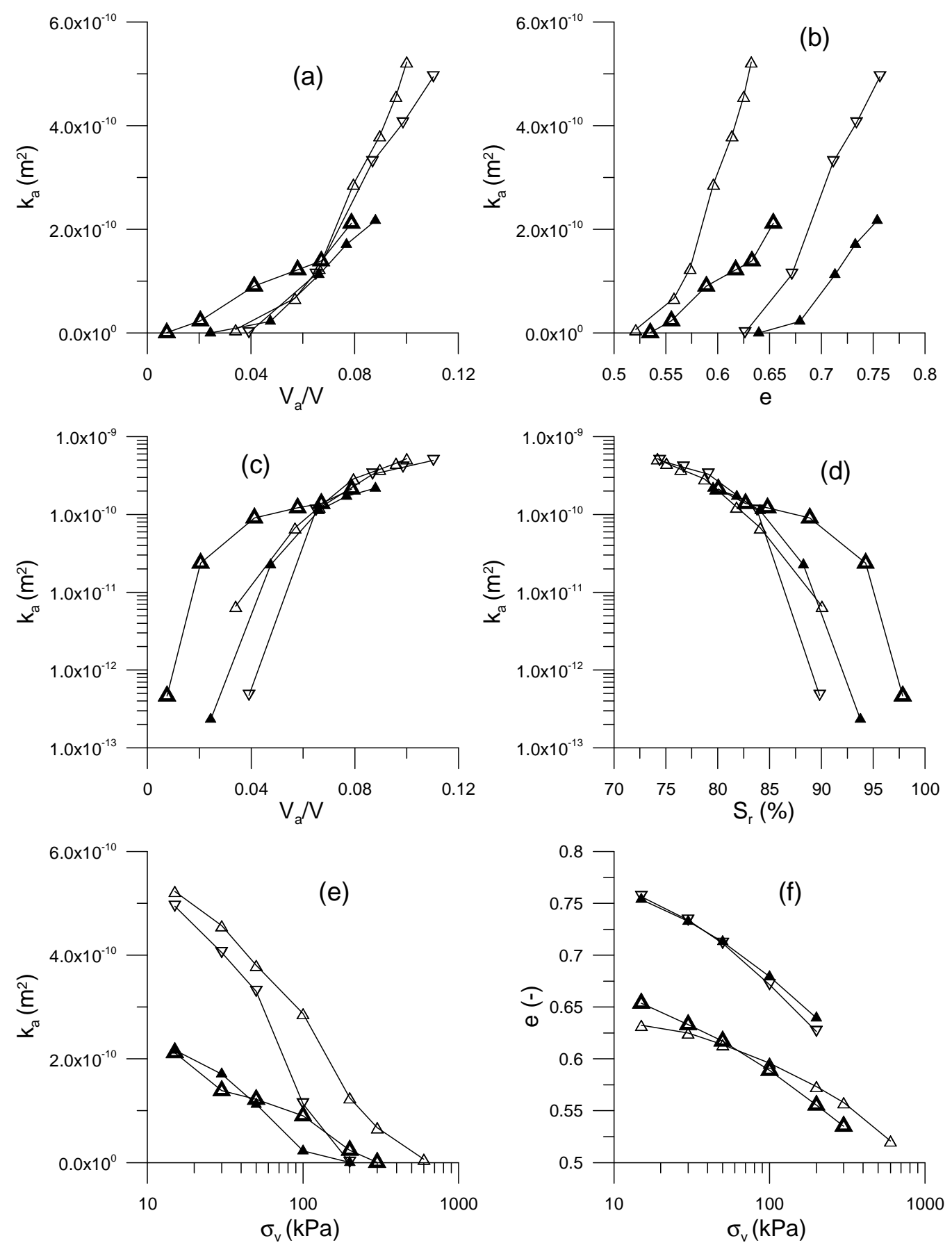

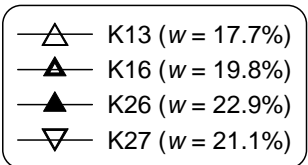

Fig. 4. Results of the undisturbed soil from Avignon $\left(k_{a}\right.$ : air permeability coefficient; $V_{a} / V$ : air-filled porosity; $e$ : void ratio; $S_{r}$ : degree of saturation; $\sigma_{v}$ : vertical stress; $w$ : water content) 

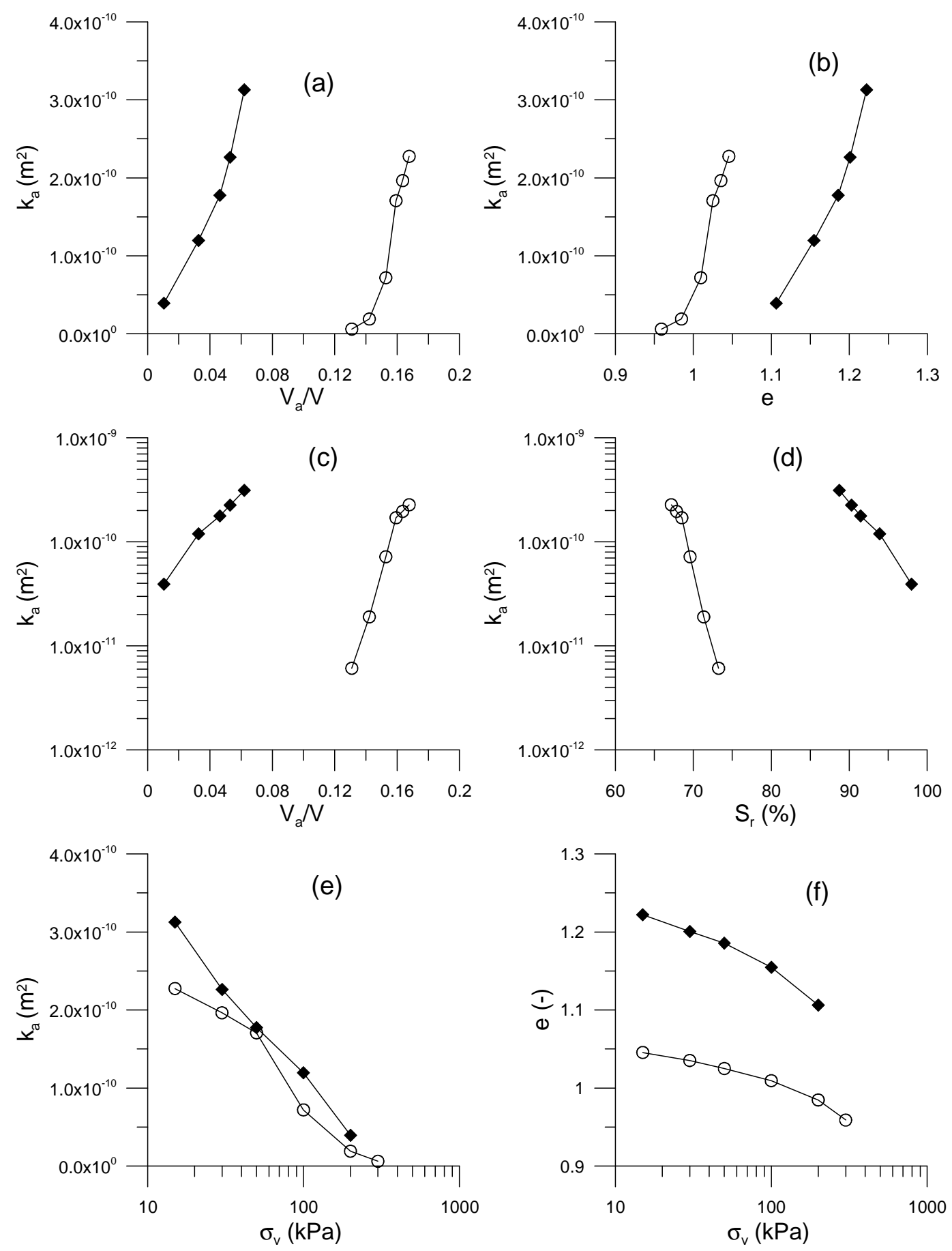

$\mathrm{K} 01(w=26.2 \%)$
$\mathrm{K} 12(w=40.5 \%)$

Fig. 5. Results of the undisturbed soil from Epernay $\left(\mathrm{k}_{a}\right.$ : air permeability coefficient; $V_{a} / V$ : air-filled porosity; $e$ : void ratio; $S_{r}$ : degree of saturation; $\sigma_{v}$ : vertical stress; $w$ : water content) 


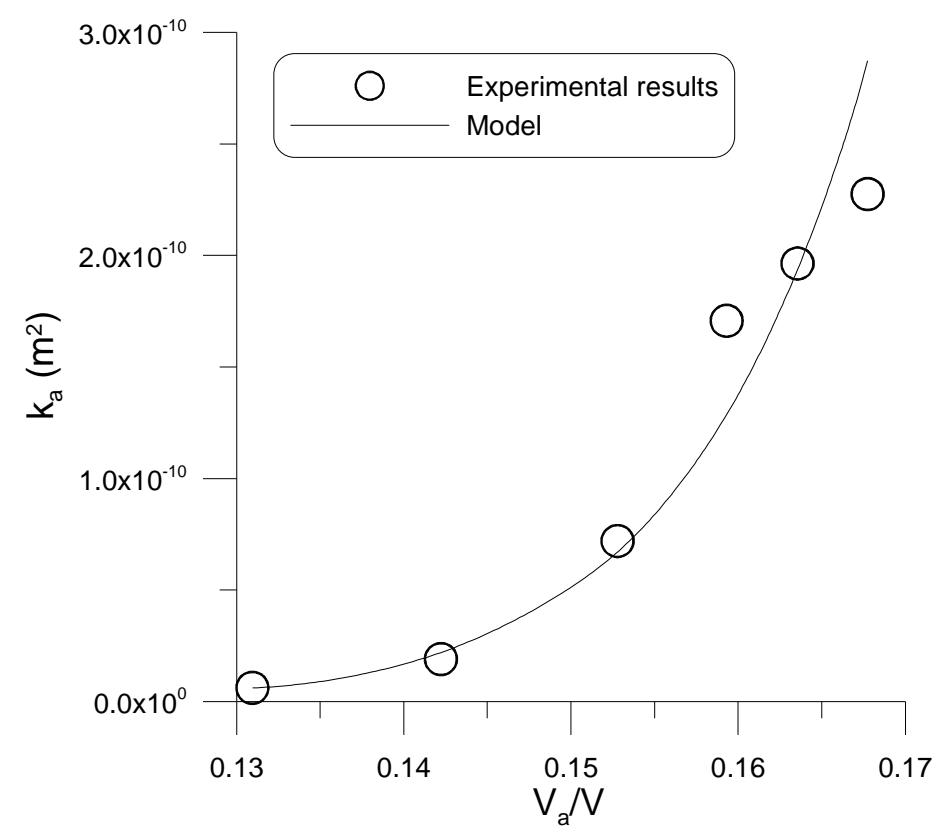

Fig. 6. Example of a comparison between the experimental results and the best fitted curve using the model of Moldrup et al. (2003). Test K01 (Soil from Epernay; undisturbed, $e_{i}=1.05 ; w_{i}=26.2 \% ; \rho_{i}=$ $\left.1.31 \mathrm{Mg} \cdot \mathrm{m}^{-3} ; S_{r i}=67 \% ; V_{a} / V=0.17\right)$. 